\title{
ANALISIS PENGGUNAAN CARBON FIBER REINFORCED PLATE PADA KAPASITAS LENTUR BETON BERTULANG DENGAN METODE ELEMEN HINGGA
}

\author{
Alvin Purmawinata ${ }^{1}$ dan Edison Leo ${ }^{2}$ \\ ${ }^{1}$ Program Studi Sarjana Teknik Sipil, Universitas Tarumanagara, Jl. Letjen S. Parman No.1 Jakarta \\ alvin.325160118@stu.untar.ac.id \\ ${ }^{2}$ Program Studi Sarjana Teknik Sipil, Universitas Tarumanagara, Jl. Letjen S. Parman No.1 Jakarta \\ edisonl@ft.untar.ac.id
}

Masuk: 17-01-2020, revisi: 21-02-2020, diterima untuk diterbitkan: 22-02-2020

\begin{abstract}
Structural strengthening is needed when structures has degrading servicability, but also required for structures that have changed functions and anticipate due to errors in design or during construction. Strengthening that's popular now is using Carbon Fiber Reinforced Polymer. Besides being strong, installation is very fast and structures can still operating. To analyze the calculations will refer to ACI 440.2R-17 because Indonesia doesn't yet have regulations about tt. Then we need finite element method as comparison method. In this research, bending capacity will be carried out on reinforced concrete beams with CFRP Plate. Modeling is done by modeling reinforced concrete blocks without strengthening (BT), and with CFRP Plate (BTF). The result is addition of CFRP plates can increase flexural capacity by $103,5 \%$ but deflection decreases by $68,9 \%$. CFRP Plate has not reached the optimum strength according to specifications. The maximum stress on CFRP on BTF beam are only 69,5\% of its tensile strength. However, according to the ACI 440.2R-17 calculation, the CFRP stress and strain are also reduced and aren't designed based on the stress and strain according to specifications. Stress design of CFRP on BTF beam according to the ACI 440.2R-17 calculation is only 38,1\% of its tensile strength.
\end{abstract}

Keywords : structural strengthening; flexural capaciy; carbon fiber reinforced polymer

\begin{abstract}
ABSTRAK
Perkuatan struktur diperlukan saat struktur sudah mengalami penurunan daya layan,selain itu juga perlu dilakukan untuk struktur yang mengalami perubahan fungsi maupun mengantisipasi akibat kesalahan perancangan maupun pelaksanaan konstruksi.. Perkuatan yang sedang populer kini adalah menggunakan Carbon Fiber Reinforced Polymer (CFRP). Selain kuat, pemasangannya sangat cepat dan operasional dapat terus berjalan tanpa terganggu. Untuk menganalisis perhitungan perkuatan struktur ini, akan mengacu kepada ACI 440.2R-17 karena Indonesia belum memiliki peraturan yang mengatur. Maka diperlukan metode lain sebagai pembanding yaitu metode elemen hingga. Dalam penelitian ini, akan dilakukan analisis kapasitas lentur terhadap balok beton bertulang yang diberi perkuatan CFRP Plate. Pemodelan dilakukan dengan memodelkan balok beton bertulang tanpa perkuatan (BT) ,dengan perkuatan CFRP Plate (BTF). Hasilnya adalah dengan penambahan CFRP Plate pada balok beton bertulang dapat meningkatkan beban kuat lentur sebesar 103,5\% namun lendutannya turun sebesar 68,9\%. CFRP Plate yang digunakan belum mencapai kekuatan optimum sesuai spesifikasi. Tegangan maksimum pada CFRP pada balok BTF hanya $69,5 \%$ dari kuat tariknya. Akan tetapi, menurut perhitungan ACI 440.2R-17, tegangan dan regangan CFRP juga direduksi dan tidak didesain berdasarkan tegangan dan regangan sesuai spesifikasi. Tegangan CFRP desain pada balok BTF menurut perhitungan ACI 440.2R-17 hanya 38,1\% dari kuat tariknya.
\end{abstract}

Kata kunci : perkuatan struktur; kapasitas lentur; carbon fiber reinforced polymer

\section{PENDAHULUAN}

\section{Latar belakang}

Struktur bangunan harus direncanakan dengan matang sebelum dilaksanakan proses pembangunan. Seiring terjadi pada masa pakai bangunan muncul beberapa masalah seperti beban hidup yang meningkat, alih fungsi bangunan, 

Hingga

perubahan tata letak mesin dan sebagainya. Untuk membongkar struktur eksisting dan membangun struktur yang baru tentunya memakan banyak tenaga, biaya, dan waktu. Perkuatan diperlukan untuk bangunan yang riskan terhadap beban baru yang diberikan maupun kesalahan perencanaan sebelum pelaksanaan konstuksi, sehingga perlu adanya peninjauan kembali atau penambahan elemen struktur tambahan. Perkuatan sebaiknya dilakukan sebelum bangunan mengalami kegagalan elemen struktur. Sedangkan jika bangunan yang telah rusak dilakukan upaya perkuatan, itu merupakan upaya untuk mengembalikan struktur dapat berdaya layan seperti semula setelah terjadi kegagalan. Jika elemen struktur tidak ditangani perbaikan atau perkuatannya secara cepat dan tepat, kerusakan dapat mempengaruhi aspek bangunan lainnya dan tentunya merusak elemen struktur lainya sehingga dapat menyebabkan bangunan tidak dapat dikembalikan fungsinya lagi. Perlu diingat bahwa biaya perkuatan struktur sangatlah murah dibandingkan kerugian korban nyawa ditambah juga proses membangun bangunan ulang kembali yang runtuh dapat mencapai berpuluh kali lipat biaya perkuatan struktur. Maka, diperlukan tindakan rehabilitasi yang dapat berupa perbaikan (retrofit) atau perkuatan (strengthening) demi keuntungan berbagai macam pihak. Seiring perkembangan zaman, perkembangan material juga ikut berkembang, material dengan kekuatan mekanis yang tinggi terus diteliti dan dikembangkan untuk digunakan dalam rekayasa teknik. Berkat perkembangan material hingga saat ini, perkuatan struktur kini memanfaatkan material Fiber Reinforced Polymer (FRP) (Sudarsana dan Widiarsa , 2008). Dalam penelitian ini, akan dibandingkan metode-metode perhitungan FRP baik dengan metode elemen hingga dengan program aplikasi , manual dengan pedoman ACI 440.2R-17 dan eksperimen yang diambil dari penelitian yang telah dilakukan sebelumnya. Data eksperimen ini diambil dari penelitian yang dilakukan oleh Endah Kanti Pangestuti, Nuroji dan Antonius (2006) yang berjudul "PENGGUNAAN CARBON FIBER REINFORCED PLATE SEBAGAI BAHAN KOMPOSIT EKSTERNAL PADA STRUKTUR BALOK BETON BERTULANG” . Sekiranya penelitian ini dapat mendorong masyarakat untuk menggunakan FRP , karena mengaplikasikannya terbilang mudah dan cepat. FRP di Indonesia masih jarang terdengar bahkan dalam dunia teknik sipil sekalipun. Sedangkan di luar negeri, sudah diciptakan aplikasi-aplikasi untuk menghitung perkuatan struktur $F R P$ untuk memudahkan para praktisi untuk melaksanakan pembangunan. Diharapkan masyarakat dapat mengenal $F R P$ dan nantinya Indonesia akan memiliki peraturan yang khusus mengatur mengenai $F R P$.

Balok beton bertulang yang ditinjau adalah balok beton bertulang yang mengalami beban statis kondisinya masih sangat baik sehingga untuk contoh penerapan di lapangan adalah saat struktur mengalami penambahan beban akibat perubahan fungsi bangunan. Kapasitas yang ditinjau hanya kapasitas lentur saja dan tulangan geser diasumsikan sudah memenuhi sehingga tidak memerlukan perkuatan geser. Perhitungan FRP yang digunakan berdasarkan spesifikasi ACI 440.2R-17.Tujuan dari penelitian ini adalah mengetahui seberapa besar pengaruh dari penggunaan $F R P$ pada balok beton bertulang terhadap kapasitas lenturnya dan juga untuk mengetahui seberapa besar perbedaan hasil dari kapasitas lentur pada balok beton bertulang yang diberi perkuatan FRP yang diperoleh berdasarkan program metode elemen hingga, hasil eksperimen dari jurnal dan teoritis.

\section{Concrete damage plasticity}

Untuk mendapatkan model yang diinginkan, digunakan concrete damage plasticity model karena sanggup memprediksi perilaku konstitutif beton. Dalam concrete damage plasticity model, beton dapat mengalami dua jenis kegagalan yaitu mekanisme kegagalan saat menerima beban tarik dan mekanisme kegagalan saat menerima beban tekan seeprti terlihat pada Gambar 1. Hubungan tegangan-regangan pada respon beton dalam pembebanan sumbu utama keadaan tarik dibedakan menjadi dua bagian, yaitu sebelum retak dan sesudah retak. Sedangkan hubungan tegangan-regangan saat kondisi setelah retak digunakan asumsi untuk penguatan tarik, perlemahan regangan dan interaksi dengan beton (Rada, 2018). Selain itu terdapat lima parameter utama yang perlu didefinisikan yaitu sudut dilatasi $(\psi)$, eksentrisitas $\left(\varepsilon_{c}\right), K c$, perbandingan kuat tekan beton dua arah dengan satu arah $\left(\sigma_{b o} / \sigma_{c o}\right)$, dan parameter viskositas $(\mu)$.Banyak penelitian yang ingin menunjukkan keterkaitan lima parameter ini dengan karakteristik beton tersebut dan memiliki angka rekomendasi seperti terlihat pada Tabel 1. 

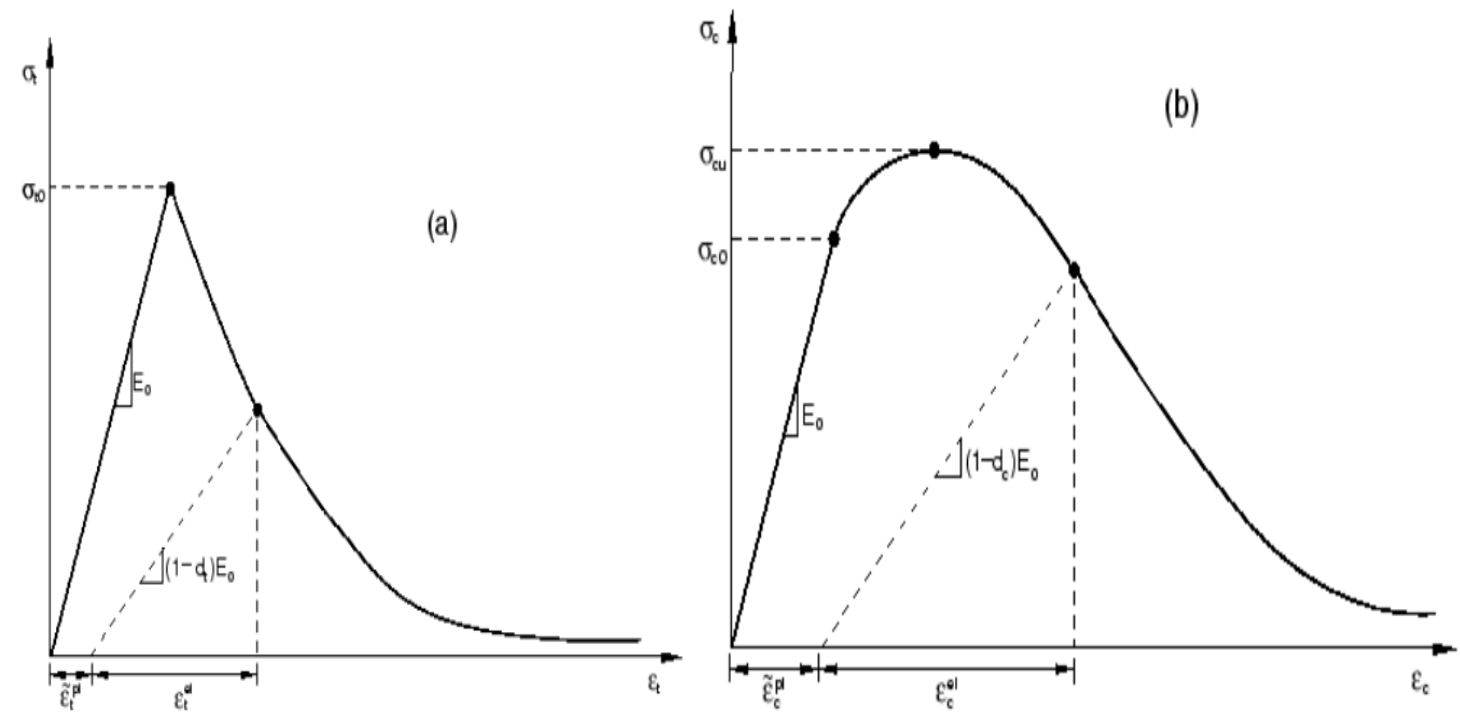

Gambar 1. Respon beton dalam pembebanan sumbu utama keadaan tarik dan tekan

(Sumber: Abaqus Analysis User's Guide, 2014)

Tabel 1 Rekomendasi nilai parameter concrete damage plasticity

\begin{tabular}{ccccc}
\hline Sudut Dilatasi $(\psi)$ & Eksentrisitas $\left(\varepsilon_{c}\right)$ & $K c$ & $\sigma_{b o} / \sigma_{c o}$ & $\mu$ \\
\hline $25^{\circ} \mathrm{s} / \mathrm{d} 40^{\circ}$ & 0,1 & $2 / 3$ & 1,16 & $0,00001 \mathrm{~s} / \mathrm{d} 0,001$ \\
\hline
\end{tabular}

(Sumber: Abaqus Analysis User's Guide, 2014)

\section{Baja tulangan}

Data material yang dibutuhkan untuk menggambarkan hubungan tegangan-regangan baja tulangan adalah modulus elastisitas $\left(\boldsymbol{E}_{\boldsymbol{s}}\right)$, poisson ratio (v), kuat leleh baja tulangan $\left(\boldsymbol{f}_{\boldsymbol{y}}\right)$, dan kuat ultimate baja tulangan $\left(\boldsymbol{f}_{\boldsymbol{u}}\right)$.Ikatan antara baja tulangan dan beton menggunakan embedded region. Tulangan dapat didesain sebagai embedded surface dengan model rebar layer atau embedded dengan menggunakan truss element. Konsep jika interaksi elemen di definisikan sebagai embedded maka akan terjadi interaksi yang sama antara elemen embedded dengan host element. Translasi yang terjadi pada baja tulangan juga akan dirasakan balok beton sehingga menciptakan interaksi antar keduanya (Rada, 2018).

\section{Carbon fiber reinforced polymer plate}

Data material yang dibutuhkan untuk menggambarkan hubungan tegangan-regangan Carbon Fiber Reinforced Polymer Plate adalah modulus elastisitas $\left(\boldsymbol{E}_{\boldsymbol{s}}\right)$, poisson ratio $(\mathrm{v})$, kuat tarik, regangan $\left(\varepsilon_{\boldsymbol{c u}}\right)$.Ikatan antara Carbon Fiber Reinforced Polymer Plate dan beton menggunakan contact surface to surface (cohesive behavior) dimana dimodelkan spesifikasi dari bahan perekat untuk menggambarkan kuat lekat antara kedua material tersebut. Komponen Carbon Fiber Reinforced Polymer Plate yang merupakan elemen shell direkatkan ke komponen balok beton yang merupakan elemen solid. Bahan perekat yang digunakan adalah epoxy yang dimodelkan modulus elastisitas. Diperlukan juga pemodelan master-slave surface yaitu balok beton yang memiliki penampang yang lebih luas bertindak sebagai master surface, dan Carbon Fiber Reinforced Polymer Plate yang memiliki bidang kontak lebih kecil bertindak sebagai slave surface.

\section{Kuat lentur beton bertulang dengan CFRP plate menurut Kuriger (2001)}

Apabila balok beton bertulang diberi CFRP Plate maka kuat lentur yang terjadi adalah hasil dari luas area penampang beton yang tertekan dengan lengan gayanya ditambah luas area FRP dikalikan dengan lengan gaya. Kondisi tegangan - regangan penampang beton dengan CFRP yang mengalami beban akibat lentur seperti yang disusulkan oleh Kuriger (2001) dapat terlihat pada Gambar 2 seperti berikut : 


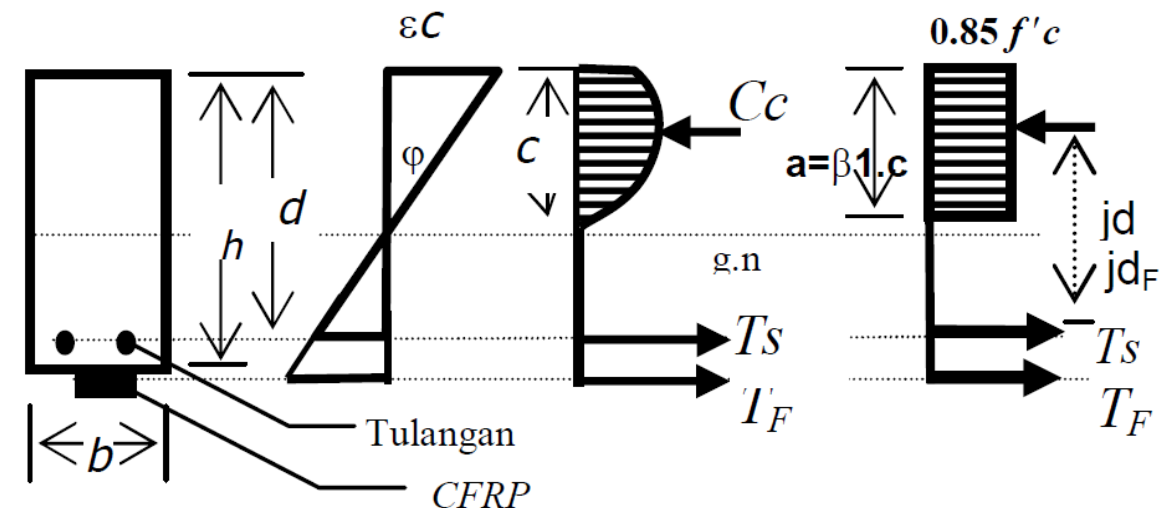

Gambar 2. Diagram $\sigma \& \varepsilon$ beton bertulang dengan CFRP (Kuriger)

(Sumber : Kuriger, 2001)

Syarat keseimbangan gaya - gaya dalam, penampang balok dengan CFRP :

Sehingga akan dihasilkan momen sebesar :

$$
\begin{gathered}
C c=T s+T_{F} \\
0,85 f^{\prime} c \cdot a \cdot b=A s \cdot f_{y}+A s_{F} \cdot f y_{F} \\
a=\frac{A s \cdot f_{y}+A s_{F} \cdot f y_{F}}{0,85 f^{\prime} c \cdot b}
\end{gathered}
$$

$$
M n=A s \cdot f_{y} \cdot \mathrm{jd}+A s_{F} \cdot f y_{F} \cdot \mathrm{jd}_{F}
$$

\section{Kuat lentur beton bertulang dengan CFRP plate menurut $A C I$ 440.2R-17}

Apabila balok beton bertulang diberi CFRP Plate maka kuat lentur yang terjadi adalah hasil dari luas area penampang beton yang tertekan dengan lengan gayanya ditambah luas area FRP dikalikan dengan lengan gaya. Kondisi tegangan - regangan penampang beton dengan $C F R P$ yang mengalami beban akibat lentur seperti yang disusulkan menurut ACI 440.2R-17 dapat terlihat pada Gambar 3 seperti berikut :

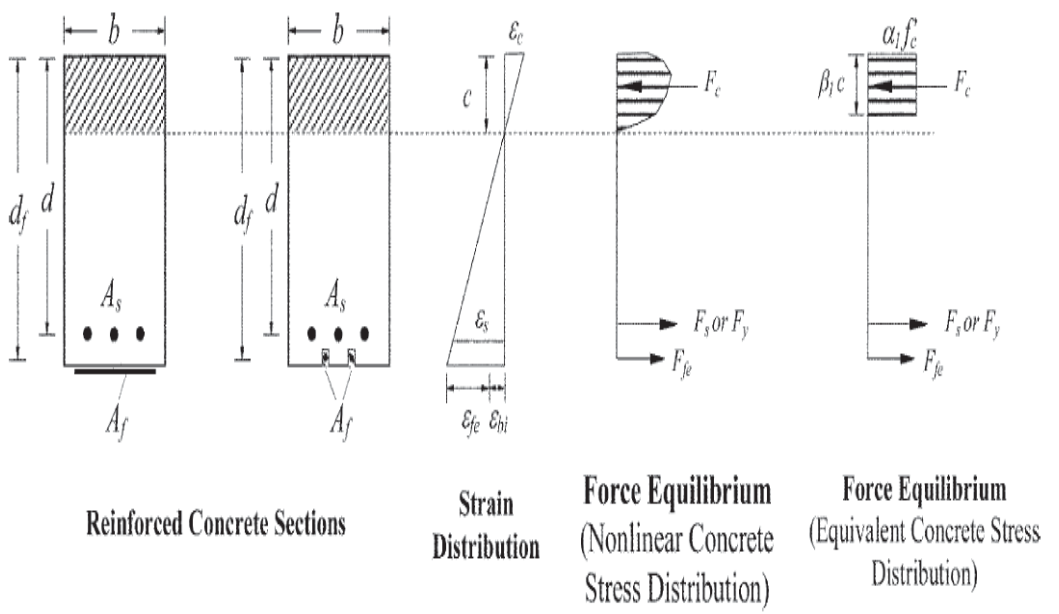

Gambar 3. Diagram $\sigma \& \varepsilon$ beton bertulang dengan CFRP (ACI 440.2R-17)

(Sumber : ACI 440.2R-17)

Menghitung kekuatan lentur dari kontribusi tulangan baja dan FRP untuk momen

$$
\begin{aligned}
& M_{n s}=A_{s} f_{s}\left(d-\frac{\beta_{1} c}{2}\right) \\
& M_{n f}=A_{f} f_{f e}\left(d_{f}-\frac{\beta_{1} c}{2}\right) \\
& M_{n}=M_{n s}+M_{n f}
\end{aligned}
$$




\section{METODE PENELITIAN}

\section{Data pemodelan penelitian}

Data balok beton ini didesain berdasarkan pengujian yang dilakukan oleh Endah Kanti Pangestuti, Nuroji dan Antonius (2006) seperti terlihat pada Gambar 4 yang berjudul "PENGGUNAAN CARBON FIBER REINFORCED PLATE SEBAGAI BAHAN KOMPOSIT EKSTERNAL PADA STRUKTUR BALOK BETON BERTULANG" dengan spesifikasi kuat tekan beton $\left(\boldsymbol{f}^{\prime}{ }_{\boldsymbol{c}}\right) \quad 32,97 \mathrm{MPa}$, kuat leleh dan ultimate baja tulangan $\left(\boldsymbol{f}_{\boldsymbol{y}}\right) \quad 336 \mathrm{MPa}$ dan 439 MPa, kuat tarik CFRP $2800 \mathrm{MPa}$, modulus elastisitas epoxy $12.800 \mathrm{MPa}$.
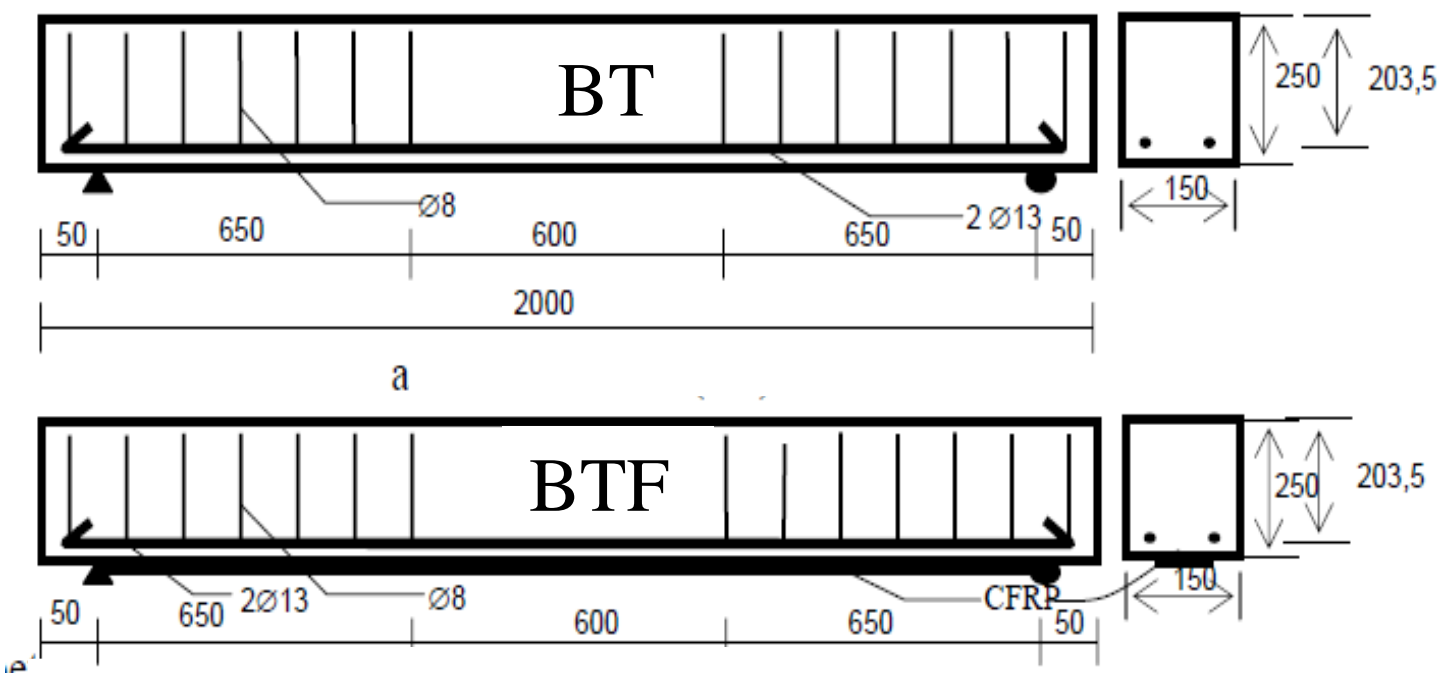

Gambar 4. Model penelitian (Sumber: Pangestuti, 2006)

\section{Prosedur pemodelan pada program finite element}

Program Finite Element digunakan untuk melakukan pemodelan serta analisis yang dilanjutkan denganmembandingkan hasil yang didapat pada Program Finite Element dengan uji eksperimen yang telah dilakukan sebelumnya. Langkah-langkah yang dilakukan dalam analisis ini, antara lain:

(a) Membuat Part

Membuat Part untuk yang dimodelkan seperti balok beton, tulangan lentur, tulangan geser, pelat baja, CFRP plate dengan masing-masing dimensi yang diinginkan.

(b) Modelisasi Material

Memodelkan masing-masing material Part dengan sifat material dengan yang aslinya dan Section properties dan Assign Section dari Part yang digunakan.

(c) Perakitan Model

Merakit model dari Section yang sudah dibuat.

(d) Merakit Bonding antara Part

Membuat Bonding Embedded Region untuk tulangan geser dan lentur dengan balok beton, ikatan Surface to Surface (cohesive behavior) untuk balok beton dengan CFRP, kemudian ikatan Surface to Surface untuk balok beton dengan pelat baja.

(e) Meshing

Meshing merupakan tahap pembagian model menjadi elemen-elemen yang lebih kecil sebagai bagian dari analisis metode elemen hingga

(f) Step

(g) Job

Memberikan perletakan dan gaya yang ingin diberikan sesuai eksperimen

Menjalankan model yang sudah dibuat sesuai beban yang diberikan 


\section{HASIL DAN PEMBAHASAN}

\section{Hasil output program finite element}

Pada pemodelan dengan Program Finite Element, komponen-komponennya tidak hanya didesain melewati kuat leleh, namun juga diperbolehkan untuk mencapai tegangan ultimate. Pemodelan ini memang memiliki konsep yang berbeda dengan perhitungan teoritis yang hanya didesain mencapai kuat leleh. Diharapkan dengan pemodelan Program Finite Element, perilaku keruntuhan yang dicapai akan menyerupai saat keadaan teoritis.

\section{Balok beton bertulang (BT)}

Pada pengujian Finite Element pada model BT, kegagalan disebabkan oleh tulangan lentur yang mencapai tegangan ultimate yaitu $439 \mathrm{MPa}$ seperti terlihat pada Gambar 5, lendutan maksimumnya adalah 38,443 mm seperti terlihat pada Gambar 6, dan dapat diperoleh grafik beban - lendutan yang dibandingkan dengan eksperimen dan teoritis seperti terlihat pada Gambar 7.

-Tegangan tulangan lentur : $439 \mathrm{MPa}$

-Lendutan : 38,443 mm

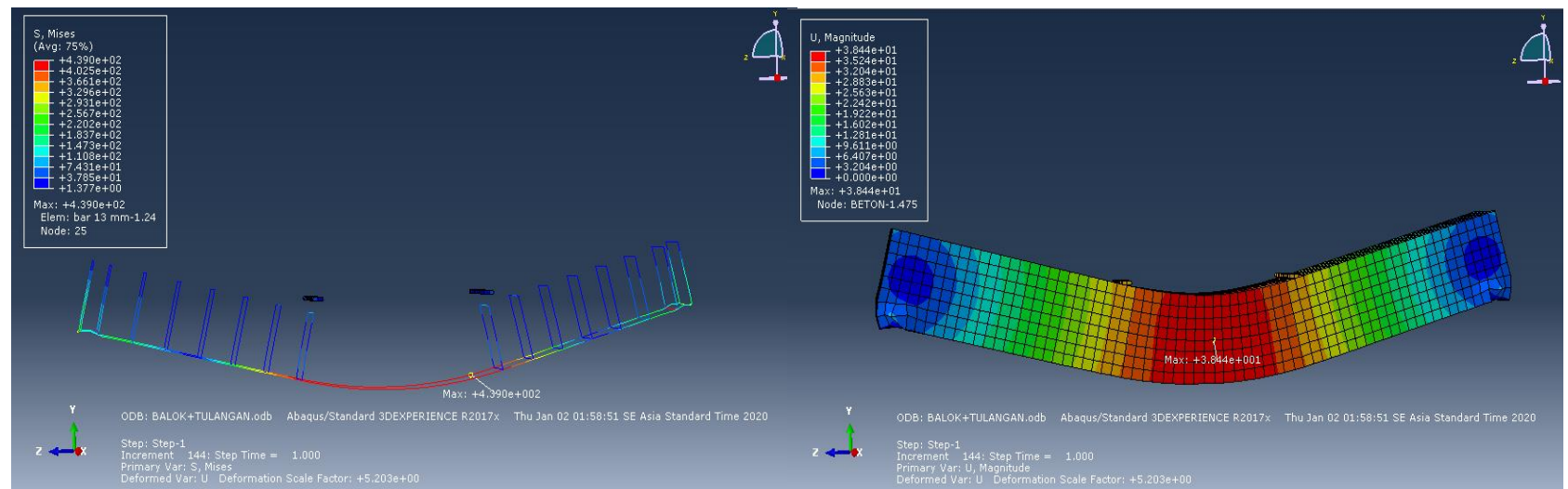

Gambar 5. Tegangan tulangan lentur (BT)

Gambar 6. Lendutan maksimum (BT)

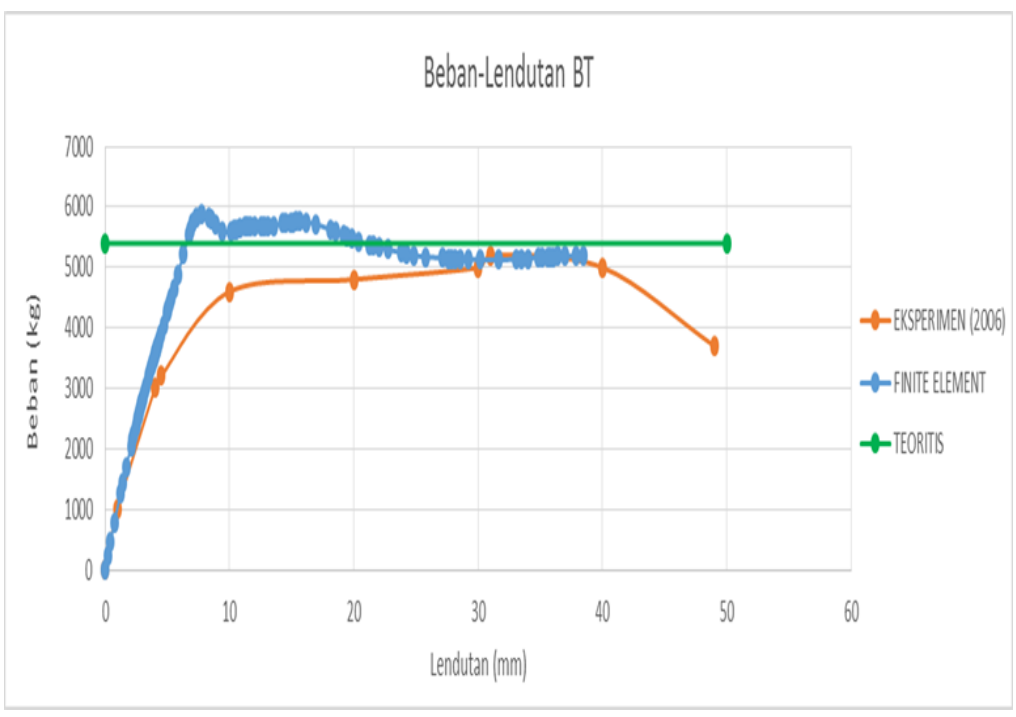

Gambar 7. Perbandingan grafik beban-lendutan (BT) 


\section{Balok beton bertulang dengan CFRP plate (BTF)}

Pada pengujian Finite Element pada model BTF, kegagalan disebabkan oleh debonding karena tegangan CFRP hanya mencapai $1945 \mathrm{MPa}$ seperti terlihat pada Gambar 8, tidak melewati kuat lelehnya yaitu 2800 MPa. Selain itu regangan pada $C F R P$ hanya mencapai 0,00934 seperti terlihat pada Gambar 9. Regangan tersebut masih jauh dari regangan spesifikasi CFRP yaitu 0,017.Tegangan yang terjadi di tulangan lentur hanya $387 \mathrm{MPa}$ seperti terlihat pada Gambar 10. Itu menandakan kegagalan tidak diakibatkan kegagalan akibat tulangan lentur. Lendutan maksimumnya adalah 11,9372 mm seperti terlihat pada Gambar 11, dan dapat diperoleh grafik beban - lendutan yang dibandingkan dengan eksperimen dan teoritis seperti terlihat pada Gambar 12.

-Tegangan tulangan lentur : $387 \mathrm{MPa}$

-Tegangan CFRP Plate : $1945 \mathrm{MPa}$

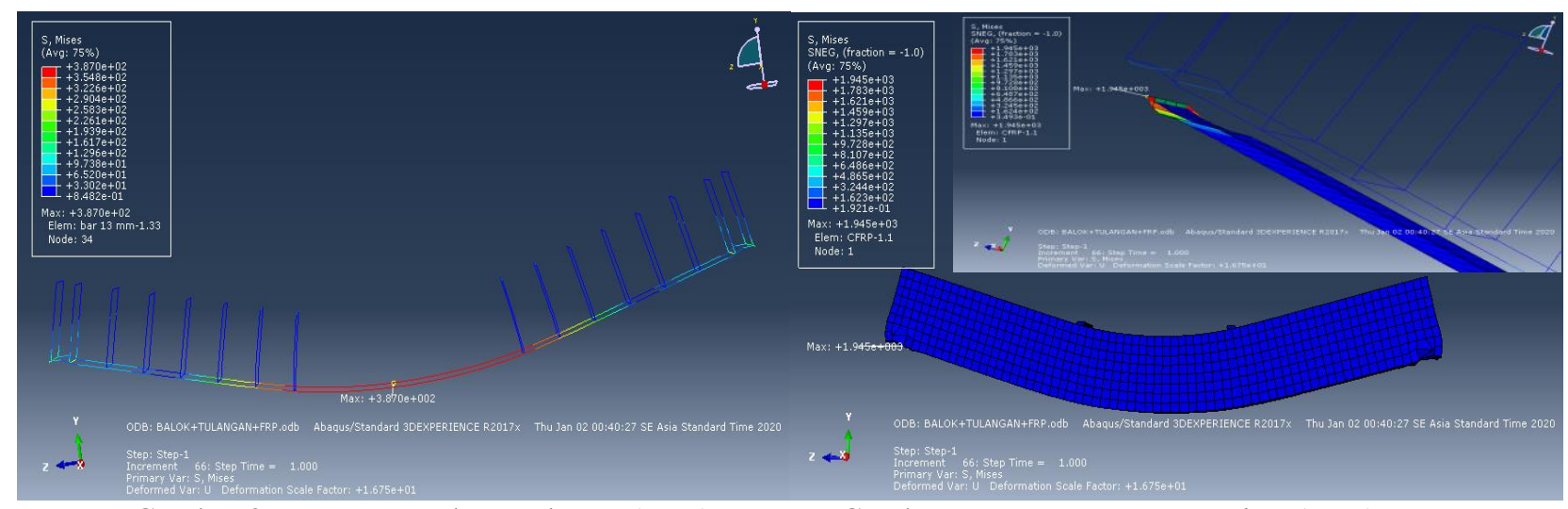

Gambar 8. Tegangan tulangan lentur (BTF)

Gambar 9. Tegangan CFRP plate (BTF)

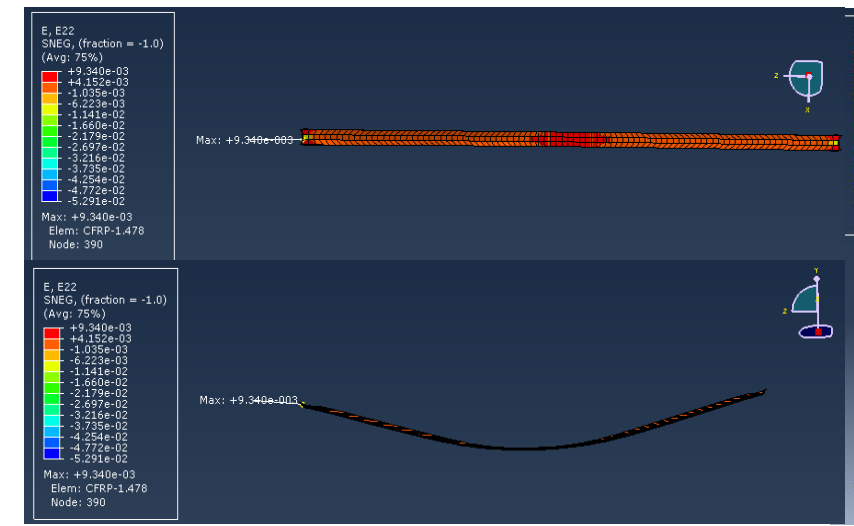

- Regangan CFRP Plate: 0,00934

Gambar 10. Tegangan CFRP plate (BTF)

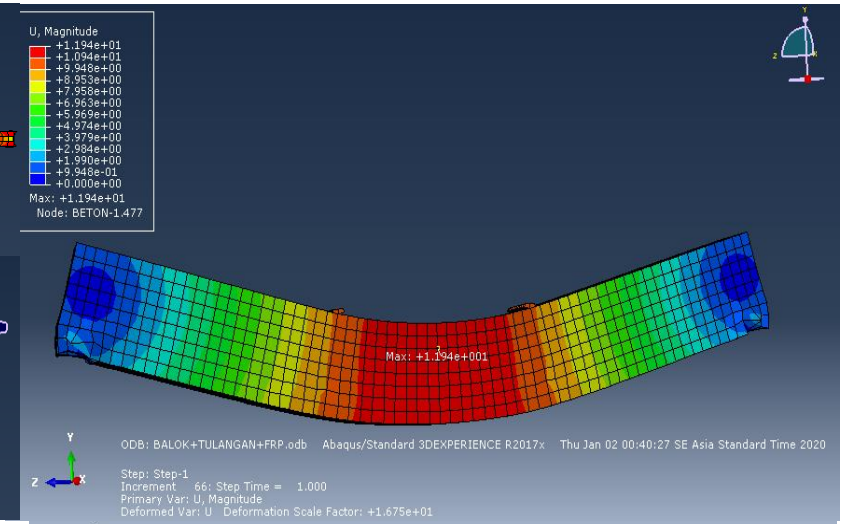

-Lendutan : 11,94 mm

Gambar 11. Lendutan maksimum (BTF)

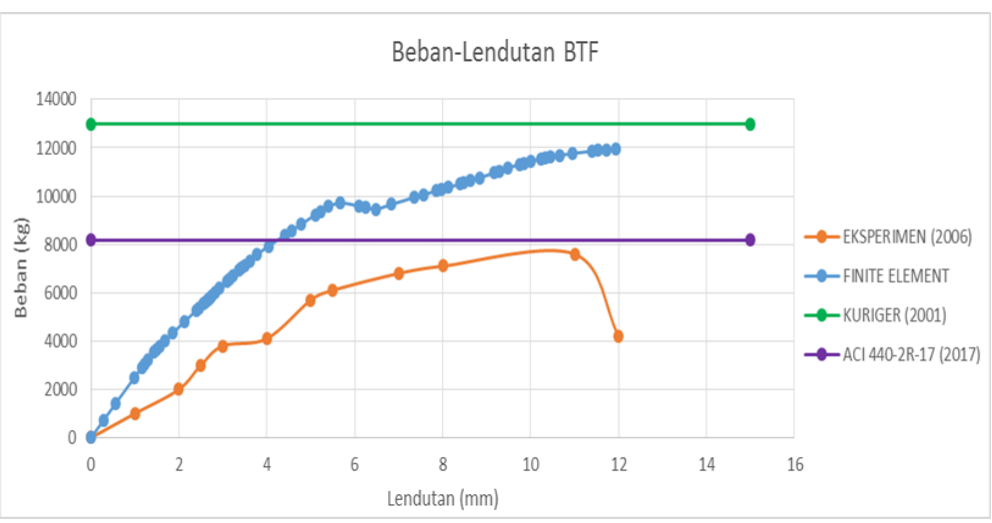

Gambar 12. Perbandingan grafik beban - lendutan (BTF) 


\section{Perbandingan hasil eksperimen, output program, dan teoritis}

\section{Beban ultimate}

Selisih Perbedaan Eksperimen (2006) dan Finite Element pada Balok BT dengan berpatokan pada Teoritis adalah $5,6 \%$ dan $+8,7 \%$ berturut-turut. Selisih Perbedaan Eksperimen (2006) dan Finite Element pada Balok BTF dengan berpatokan pada Teoritis Kuriger (2001) adalah $-41,5 \%$ dan $+8 \%$ berturut-turut. Selisih Perbedaan Eksperimen (2006) dan Finite Element pada Balok BTF dengan berpatokan pada Teoritis ACI 440.2R-17 (2017) adalah -7 \% dan $+46,1 \%$ berturut-turut.

\section{Lendutan}

Selisih Perbedaan Finite Element pada Balok BT dengan berpatokan pada Eksperimen (2006) adalah -21,5 \%. Selisih Perbedaan Finite Element pada Balok BTF dengan berpatokan pada Eksperimen (2006) adalah $+7,9 \%$.

\section{KESIMPULAN DAN SARAN}

\section{Kesimpulan}

Berdasarkan hasil pemodelan dengan menggunakan program Finite Element, dapat disimpulkan beberapa hal, yaitu:

(a) Penambahan CFRP Plate secara eksternal pada model Finite Element BTF terhadap BT dapat meningkatkan beban kuat lentur sebesar $103,5 \%$, namun lendutan maksimumnya turun sebesar $68,9 \%$

(b) CFRP Plate eksternal pada model Finite Element belum mencapai tegangan dan regangan maksimum sesuai spesifikasi, sehingga dapat dikatakan ikatan antar material belum optimum. Tegangan maksimum pada $C F R P$ pada balok BTF adalah 69,5\% Akan tetapi, menurut perhitungan ACI 440.2R-17, tegangan dan regangan CFRP juga direduksi hingga 38,1\% dari kuat tariknya dan tidak didesain berdasarkan tegangan dan regangan sesuai spesifikasi.

(c) Selisih persentase perbedaan kuat lentur antara Finite Element dengan Teoritis pada model Balok Beton Bertulang (BT) hanya 8,7 \%. Perbedaan itu dikarenakan perhitungan Finite Element mengalami kegagalan saat baja tulangan mencapai tegangan ultimate sedangkan Teoritis hanya menggunakan kekuatannya sampai tegangan leleh. Bagian beton yang mengalami tarik juga diperhitungkan menyumbang kapasitas lentur pada Finite Element.

(d) Selisih persentase perbedaan kuat lentur antara Finite Element dengan ACI $4402 R-17$ pada model Balok Beton Bertulang dengan CFRP Plate (BTF) adalah 46,1\%. Perbedaan itu dikarenakan saat CFRP Plate bekerja, Finite element berasumsi epoxy bekerja dengan sempuna. ACI 440.2R-17 memiliki teori yang lebih konservatif terkait bonding antara dua material. Setiap analisis memiliki pendekatan yang berbeda terkait ikatan material komposit maka hasilnya pun berbeda.

(e) Setiap analisis memiliki tegangan desain pada CFRP Plate yang semuanya berada di bawah batas kuat tariknya kecuali Teori Kuriger yang menggunakan kuat tarik sebagai analisis perhitungan.

\section{Saran}

Setelah melakukan pemodelan menggunakan program Finite Element, terdapat beberapa saran yang dapat diberikan, antara lain:

(a) Untuk melakukan analisis balok beton bertulang perlu dilaksanakan pengujian material yang diuji terutama saat kondisi plastis, sehingga hasil pengujian Finite Element dapat memiliki hasil yang lebih akurat.

(b) Perlu diadakan pengujian Finite Element dengan variasi tebal dan lebar yang lebih bervariasi agar diperoleh komposisi yang optimal untuk penggunaan CFRP Plate, Selain itu, perlu juga dilakukan penelitian mengenai penempatan CFRP Plate yang optimum dengan meminimumkan material CFRP Plate yang digunakan untuk mencapai kekuatan yang maksimum.

(c) Perlu dicoba menggunakan material epoxy yang memiliki modulus elastisitas yang lebih tinggi dari modulus elastisitas beton agar tercipta bonding yang baik antara material komposit.

\section{DAFTAR PUSTAKA}

Abaqus Analysis User's Guide (6.14). Dassault System, 2014.

ACI Committee . Guide for the Design and Construction of Externally Bonded FRP Systems for Strengthening Concrete Structure, ACI 440.2R-17, Michigan : American Concrete Institute, Farmington Hills, 2017. 
Kuriger,Rex., Shad Sargand, Ryan Ball dan Khairul Alam .Analysis of Composite Reinforced Concrete Beams, Ohio : Department of Mechanical Engineering, Ohio University, 2001.

Pangestuti, Endah Kanti., Nuroji dan Antonius. Penggunaan Carbon Fiber Reinforced Plate sebagai Bahan Komposit Eksternal pada Struktur Balok Beton Bertulang.PILAR Vol.15.No.2 (September 2006) : 86-94

Rada,Stefanus. Pemodelan Metode Elemen Hingga Balok Beton Bertulang dengan Perkuatan CFRP (Carbon Fiber Reinforced Polymer) yang Dikenai Lentur dan Geser, Yogyakarta : Pasca Sarjana Universitas Atma Jaya Yogyakarta, 2018.

Sudarsana, I.K dan Widiarsa, I.B.R. Perilaku Runtuh Balok Beton Bertulang yang Diperkuat dengan Lapis Glass Fiber Reinforced Polymer (GFRP), Jurnal Ilmiah Teknik Sipil, 2008. 
